ranges and valleys in a series of 'jogs', from the divide leading to the Bow River valley on the north-east to Columbia River on the south-west. It lies wholly within the Province of British Columbia and consists of four different segments: the northern end comprises the drainage basin at the head of Vermilion River; the middle section is a belt at right angles to the first, following the Vermilion River across the general trend of Vermilion Range and extending into the Mitchell Range in the south-west; the main southern part of the Park is a strip along the Kootenay River valley; and a fourth part includes a 'jog' to westward, which takes in the valley of Sinclair Creek nearly to its junction with Columbia River. An attractive guide to the Park has recently been prepared by the Geological Survey of Canada Department of Mines and Technical Surveys, Ottawa, as Miscellaneous Report No. 9 (Kootenay National Park-Wild Mountains and Great Valleys, by David M. Baird. Pp. vi +94 . Ottawa: Queen's Printer, 1964. 1.50 dollars).

\section{Irish Tubificidae}

THE study of the Irish Tubificidae has been largely neglected since the publication of a check list by Southern in 1909. The only other person to have concerned himself with them was Friend, whose taxonomic investigations and identifications are in general considered not to be wholly reliable. A complete revision of the Irish tubificids has long been overdue and, in a paper by C. R. Kennedy, of the Department of Zoology, University of Liverpool, an attempt is made to bring knowledge of them up to date and into line with the European species (Proceedings of the Royal Irish Academy, 63, Section B, No. 13. Dublin: Hodges, Figgis and Co., Ltd., 1964. 2s. 6d.). The literature pertaining to the Irish tubificids is reviewed and, in addition, the results of an examination of Southern's specimens are presented together with information gained from visiting sites and making further collections. It has proved possible to confirm or correct the identity of most of the earlier records by an investigation of their descriptions, by examination of specimens or by both, and to bring the nomenclature up to date. As a result of this survey, seventeen species are now recognized as existing in Ireland, six of which are new Irish records. All of these are encountered, more or less commonly, in Britain.

\section{New Medicines}

According to surveys conducted by Research Services, Ltd., 89 per cent of general practitioners consider that new medicines have been of great importance in recent medical advances in the control of disease, and 80 per cent of both general practitioners and the general public feel that it would be a serious matter if lower profits for pharmaceutical manufacturers were to reduce their work in developing these new medicines (Attitudes towards the Pharmaceutical Industry amongst Family Doctors and the General Public, 1962 and 1964). The public in general tended to overestimate the amount spent on National Health Service medicines. Of every $£ 100$ of National Health Service expenditure, about $£ 13$ went on medicines (in general practice and in hospital); two-thirds of the general public believed the figure to be more than $£ 20$, and two-fifths believed it to be more than $£ 30$. Moreover, although the proportion of total National Health Service costs spent on medicine has remained constant since 1959, 81 per cent of the general public and 67 per cent of general practitioners had the impression that it was increasing. General practitioners were asked what sources of information they relied on to keep up to date with pharmaceutical discoveries. 71 per cent named articles in medical journals; 36 per cent manufacturers' representatives; 25 per cent discussion with colleagues; 24 per cent manufacturers' literature through the post; 21 per cent the Government-sponsored publication, Prescribers' Journal; and 18 per cent advertise. ments in medical journals. Refresher courses, medical society meetings, the Monthly Index of Medical Specialities, discussions with pharmacists, hospitals and consultants were among other sources of information mentioned. The Association of the British Pharmaceutical Industry has a code which bans undesirable marketing practices among its member companies. This was revised recently after consultation with the British Medical Association. Two-thirds of the general practitioners interviewed could not provide examples of cases they felt should have been prevented by this code. The most commonly mentioned type of undesirable practice was price-cutting, mentioned by 5 per cent of doctors. Many of the individual instances related to events which occurred before the existence of the code. 89 per cent of the public said they had confidence in the safety of medicines prescribed for them by the doctor; only 4 per cent said they had not. The reasons given by the majority indicated an overwhelming confidence in their doctor, 71 per cent saying that their confidence was based on faith in their doctor and his prescribing. Copies of the survey are available from the Office of Health Economics, 62 Brompton Road, London, S.W.3.

\section{Announcements}

Prof. F. S. Dalnton, at present professor of physical chemistry in the University of Leeds, has been appointed to succeed Dr. B. L. Hallward as Vice-Chancellor of the University of Nottingham as from October 1965.

A meeting of the Basic Science Section of the British Ceramic Society on "Physics and Chemistry of Ceramic Surfaces" will be held in London during December 15-17. Further information can be obtained from Dr. J. P. Roberts, Houldsworth School of Applied Science, the University, Leeds 2.

A Conference entitled "A Scientific Basis of Maximum Permissible Levels", arranged by the British Institute of Radiology, will be held in the Edward Lumley Hall, Royal College of Surgeons, London, W.C.2, on December 8. Further information can be obtained from the British Institute of Radiology, 32 Welbeck Street, London, W.1.

THE second annual conference on "Solid-State Physics", arranged by the Institute of Physics and the Physical Society, will be held at the H. H. Wills Physics Laboratory, University of Bristol, during January 5-8. Further information can be obtained from the Administration Assistant, Institute of Physics and the Physical Society, 47 Belgrave Square, London, S.W.1.

Two joint meetings of the Western Section of the Society for Analytical Chemistry and the Cardiff and District Section of the Royal Institute of Chemistry will be held at the College of Technology, Newport, and University College, Cardiff, on November 27 and December 11 , respectively. At the first meeting, Dr. T. S. West (Imperial College of Science and Technology) will present a paper entitled "Complexometric Methods in Analytical Chemistry", and at the second, Dr. E. V. Truter (University of Leeds) will speak on "Thin-layer Chromatography". Further information can be obtained from the Society for Analytical Chemistry, 14 Belgrave Square, London, S.W.1.

A conference on "Optics in Process Control", organized by the Optical Group of the Institute of Physics and the Physical Society, will be held at the Manchester College of Science and Technology during January 6-8. The main topics of discussion will include: optical monitoring and inspection; metrology and machine tool applications; optical methods of analysis; control of photographic processes; tracking and ranging devices; optics in the semiconductor industry; optics in computer technology. Further information can be obtained from the Administration Assistant, Institute of Physies and the Physical Society, 47 Belgrave Square, London, S.W.1. 